\title{
GILL NET SAMPLING STANDARDISATION IN LARGE RIVERS OF FRENCH GUIANA (SOUTH AMERICA).
}

\author{
F.L. TEJERINA-GARRO and B. DE MÉRONA
}

Laboratoire d'hydrobiologie, Institut de Recherche pour le Développement - Cayenne,

Route de Montabo, B.P. 165, 97323 Cayenne Cedex, France.

\begin{abstract}
In this paper is analyzed the sampling efficiency of repeated batteries of mixed gillnets mesh size from 15 to $70 \mathrm{~mm}$. The study was conducted in three French Guiana rivers : the Sinnamary, Comté and Malmanoury rivers. Efficiency of sampling methods is one of the problems faced by freshwater ichthyologists. If the choice of one approach must consider its efficiency and cost/profit rates for a determinate level of accuracy, the abiotic characteristics of the environment sampled has also an important role in this process. Large rivers, like those sampled in French Guiana, present specific abiotic characteristics that prevent the large use of non-selective sampling methods like electrofishing or rotenone poisoning. Differently, other sampling gear such as gillnets is used frequently. This kind of gear presents known bias problems related to fish size or species. However, bias can be diminished through the use of mixed gillnets mesh size, which efficiency was previously determined. Results of Principal Component Analysis (PCA) suggest that gillnet mesh size 15 to $35 \mathrm{~mm}$ are the most efficient in sampling fish fauna in the rivers sampled. Regarding the number of repeated batteries, the analysis of Catch Per Unit of Effort (CPUE), species richness, sample structure (rank correlation) and the examination of their variance suggest that the use of three batteries gives a good estimation for the fraction of the fish community sampled.
\end{abstract}

\section{STANDARDISATION DE L'ÉCHANTILLONNAGE AU FILET MAILLANT DANS LES GRANDS COURS D'EAU DE LA GUYANE FRANÇAISE (AMÉRIQUE DU SUD).}

\section{RÉSUMÉ}

Cette étude porte sur l'analyse du compromis entre l'effort d'échantillonnage et la minoration des variabilités expérimentales en utilisant de façon répétitive des batteries de filets maillants de 15 à $70 \mathrm{~mm}$. L'étude a été développée dans trois cours d'eau de la Guyane française : le Sinnamary, la Comté et la Malmanoury. L'efficacité des méthodes d'échantillonnage est un des problèmes majeurs dans le quotidien des ichtyologistes. Le choix d'une méthode doit considérer son efficacité et la relation coût/bénéfice pour arriver à un certain niveau de précision des résultats. Toutefois, dans ce processus les caractéristiques du milieu à échantillonner ont un rôle important. Les cours d'eau, comme ceux trouvés en Guyane française, présentent certaines particularités qui empêchent l'utilisation des méthodes non sélectives comme la pêche électrique ou l'utilisation d'ichtyotoxique. En revanche, d'autres types de matériel de pêche, comme les filets maillants sont couramment utilisés. Ce matériel présente des problèmes de biais par 
rapport aux espèces et à la taille des poissons. Toutefois, ce biais peut être réduit en utilisant des filets de différentes mailles, dont l'efficacité a été démontrée préalablement. Le résultat de cette étude suggère que les filets de maille 15 à $35 \mathrm{~mm}$ de vide de maille sont les plus efficaces pour échantillonner les peuplements de poissons des rivières ici considérées. Les résultats de l'analyse sur le nombre de batteries répétées basés sur la variance de la capture par unité d'effort, de la richesse spécifique et de la structure de l'échantillon (corrélation de rang) suggèrent que l'utilisation de trois batteries représente un compromis acceptable entre l'effort d'échantillonnage et la précision de l'estimation des caractéristiques du peuplement de poissons.

\section{INTRODUCTION}

One problem faced by many fish ecologists is to get unbiased estimates of fish assemblage in a studied habitat. A number of methods were developed (BACKIEL and WELCOMME, 1980 ; BAYLEY, 1985), but each of them is limited in its use by constraints related to habitat characteristics.

In opening the "Large River Symposium » held in Honey Harbour (Ontario) in 1986, D.P. DODGE defined large rivers as those large enough to intimidate research workers (HYNES, 1989). Although it is obviously difficult to set an arbitrary boundary between small and large rivers, authors generally agree that above $1 \mathrm{~m}$ deep and about $20 \mathrm{~m}$ wide, a river can be considered as large (KELLERHALS and $\mathrm{CHURCH}, 1989 ; \mathrm{CHURCH}, 1992$ ). In these habitats the more efficient catching methods for fish are generally inapplicable. Direct observation by snorkelling cannot be done because of the low water transparency. Trawling is impeded by frequent presence of rocks or woody debris at the bottom. Electric fishing has been used in certain occasions (NELVA et al., 1979 ; PERSAT and COPP, 1990) but the method is limited. In forest rivers, like those encountered in French Guiana, water conductivity is as low as $30 \mu \mathrm{S}$ and electric fishing is only possible through heavy equipment. Depth of many aquatic environments and fish behaviour make also this technique inadequate for large rivers (LAMARQUE, 1990). The use of ichthyotoxics, which is considered a very efficient method for catching the whole community of fish, is limited to small and shallow areas and cannot be used repeatedly. PONTON and COPP (1997) using the rotenone in Guiana rivers appointed that in deeper places the retrieval efficiency of sunk fishes decreases, greater water velocities require greater quantities of toxicants which can increase the risk of mortality of fishes downstream the place sampled. Seine nets have been used in few occasions for biomass estimates purposes, but the method is restricted to relatively clean biotopes and disturbs the habitat (BAYLEY, 1982 ; LAGLER et al., 1971).

Finally gill netting remains one of the few available methods for catching fish in most large rivers. Naturally, fish ecologists know how uncertain this method is, mainly because of selectivity problems (HAMLEY, 1975) although, it revealed efficiency in detecting changes in fish community structure of floodplain lakes when compared to high efficient methods like electrofishing (TEJERINA-GARRO et al, 1998). The probability of capture of an individual fish using gilinets depends not only on the adequacy of its size to net mesh size (HAMLEY and REGIER, 1973 ; HENDERSON and WONG, 1991 ; HELSER and CONDREY, 1991), but also on its shape and behaviour (HAMLEY, 1975 ; JENSEN, 1986). Individual capture is also submitted to chance. This situation leads to the statement that getting an unbiased sample of a diverse fish assemblage in large rivers seems unrealistic. However, realistic is the possibility to compare samples trying to reduce the bias. Mesh size selectivity can be reduced using large range of gillnets of different mesh sizes and using a large number of nets of each mesh size can reduce chance parameters. Obviously, there is a limit in the number of nets that a research team can handle. This 
study proposes a method to determine the best compromise between the number of mesh sizes and the number of nets of each size, which must be used in order to get a stabiiized sample in large rivers.

\section{MATERIAL AND METHODS}

The principle of the method used in this study was to set a large number of gillnets in the same area within a limited period of time. Gillnets were organized in batteries; each battery was composed by nine nets of mesh sizes 15,20,25,30,35,40,50,60 and $70 \mathrm{~mm}$ between adjacent knots. The choice of this combination of mesh sizes was determined by earlier sampling. A $10 \mathrm{~mm}$ gillnet has a very low efficiency, rapidly filled by debris or algae. Due to the scarcity of very large species in French Guiana freshwaters, the capture of gillnets of $70 \mathrm{~mm}$ mesh size is only accidental, making the use of nets of larger mesh size inadequate. Each net was $25 \mathrm{~m}$ long and $2 \mathrm{~m}$ high. In order to get general results samplings took place in different periods of the year and in different rivers.

\section{Five samples were taken :}

- In the Sinnamary River upstream from the Petit-Saut reservoir (Figure 1). Sampling took place two times, in November 1995 with 5 batteries and in November 1996 with 7 batteries. Sampling was done in three different sites distant about $25 \mathrm{~km}$ one from other. Correlation of normalized species abundance between the 3 sites are highly significant (Table I). In the three areas the river width varied between 26 and $63 \mathrm{~m}$ and riverbanks were covered by dense and continuous primary vegetation.

- In the Sinnamary River, downstream from Petit-Saut dam, sampling took place in April 1997 in a section of $800 \mathrm{~m}$ at about $30 \mathrm{~km}$ from the dam (Figure 1). Five batteries were used. River width in sampling area ranged from 59 to $112 \mathrm{~m}$. The river flows through the coastal plain and is bordered by primary forest.

- In the Malmanoury River, a small coastal watercourse crossing the coastal plain, one sample was taken in April 1997 (Figure 1). Six batteries of gillnets were set in a section of about $800 \mathrm{~m}$ located in the middle course. In the sampled area the channel width varied from 25 to $35 \mathrm{~m}$. This river runs throughout forest, savanna and some disturbed areas also.

- In the Comte River one sample was taken in March 1998. The sample took place in the most upstream half of the river (Figure 1). Six batteries were used. The river width ranges between 23 and $45 \mathrm{~m}$ and the banks are covered with vegetation.

\section{Table I}

Correlation values among the three stations sampled in the upstream Sinnamary in 1995 and 1996. $A=$ Saut Takari Tanté, $B=$ Saut Dalle, $C=$ Saut Deux Roros. ${ }^{\star} n=36, p<0.01 ;{ }^{\star \star} n=44, p<0.01$.

\section{Tableau I}

Valeurs de la corrélation entre les trois stations échantillonnées dans le Sinnamary amont en 1995 et 1996. $A=$ Saut Takari Tanté, $B=$ Saut Dalle, $C=$ Saut Deux Roros. ${ }^{\star} n=36, p<0.01 ;{ }^{* \star} n=44, p<0.01$.

\begin{tabular}{|c|c|c|c|c|c|c|c|}
\hline & & A & $\begin{array}{c}1995 \\
\text { Station } \\
B\end{array}$ & C & A & $\begin{array}{c}1996 \\
\text { Station } \\
B\end{array}$ & C \\
\hline Station & $\begin{array}{l}A \\
B \\
C\end{array}$ & $\begin{array}{c}1 \\
0.695^{\star} \\
0.690^{*}\end{array}$ & $\begin{array}{c}1 \\
0.726^{*}\end{array}$ & 1 & $\begin{array}{c}1 \\
0.646^{\star \star} \\
0.703^{\star \star}\end{array}$ & $\begin{array}{c}1 \\
0.680^{\star *}\end{array}$ & 1 \\
\hline
\end{tabular}




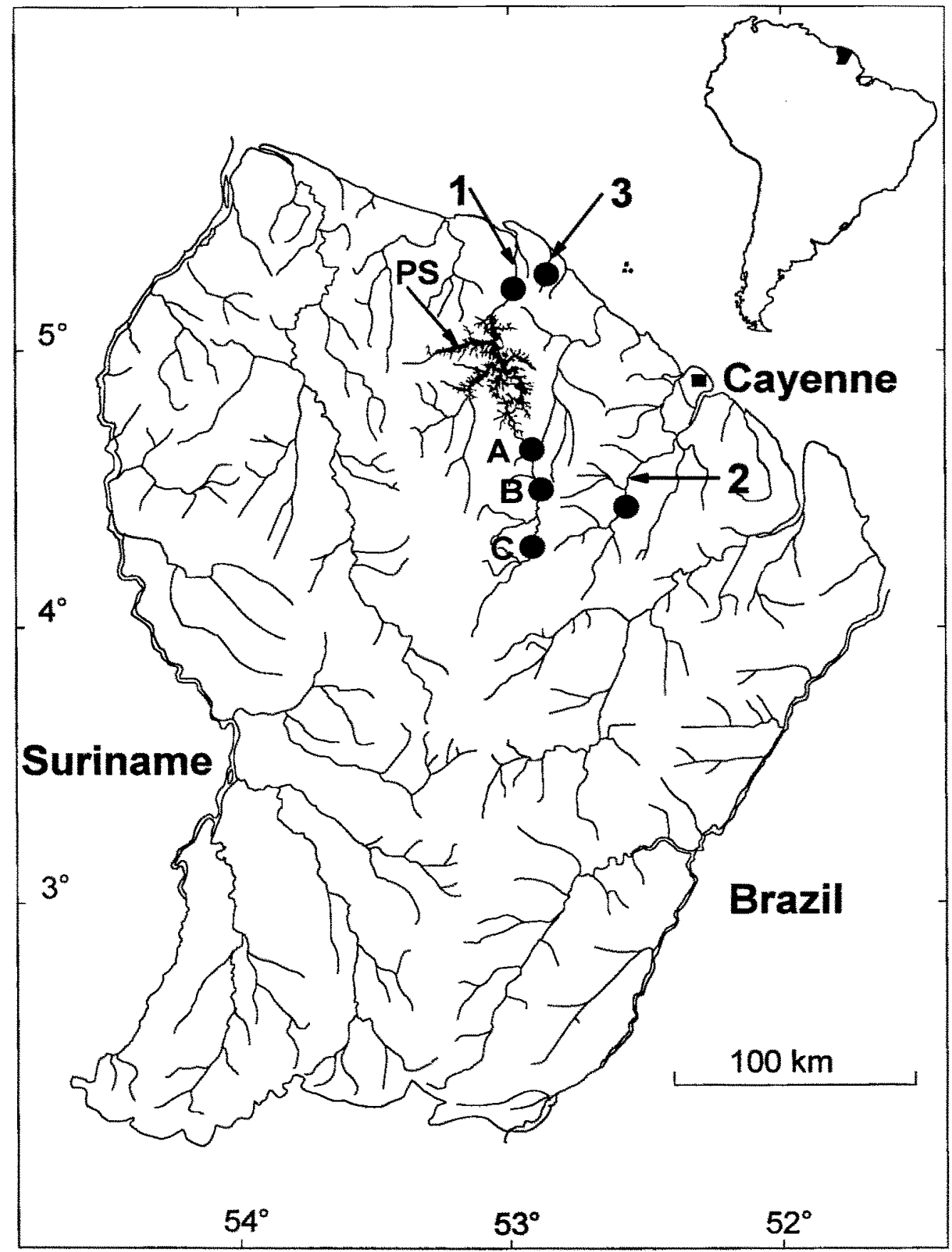

Figure 1

Localization of the Sinnamary River (1), Comté River (2), and Malmanoury River (3) in French Guiana. Dots represents sampling sites. In Sinnamary upstream three sites were sampled $(A=$ Saut Takari Tanté, $B=$ Saut Dalle, $C$ = Saut Deux Roros) and one area downstream the hydroelectric dam of Petit-Saut (PS).

Figure 1

Localisation du fleuve Sinnamary (1), de la rivière Comté (2) et du fleuve Malmanoury (3) en Guyane française. Les points indiquent les sites d'échantillonnage. Sur le fleuve Sinnamary trois sites ont été échantillonnés en amont ( $A=$ Saut Takari Tanté, $B=$ Saut Dalle, $C=$ Saut Deux Roros) et un en aval du barrage de Petit-Saut (PS). 
The nets were set parallel to shore line, in places with low current. They were deployed at $5 \mathrm{pm}$ and retrieved at 7 am. Tentative of fishing during day showed that additional capture, in terms of number of specimens as well as species, is negligible.

Captured fishes were identified in field using keys for adults elaborated by ROJAS-BELTRAN (1984), SANTOS et al. (1984), PLANQUETTE et al. (1996), and BOUJARD et al. (1997).

In order to know the contribution of each gillnet mesh size to total variance a Principal Component Analysis (PCA) was conducted on the matrix species frequency by mesh size for each sample using statistical package ADE-4 (THIOULOUSE et al., 1997). Each column of mesh size gillnets was transformed (standardized) and the PCA analysis was conducted using the covariance matrix. This kind of analysis and the transformation allows to compare heterogeneous variables in nature and scale (SIMIER, 1998).

In order to determinate the optimal number of gillnets batteries, we generated randomly, without reposition, batteries composed by five nets of mesh size 15, 20, 25, 30 and $35 \mathrm{~mm}$. Fifty random draws were made for each number of batteries used in each river sampled. The parameters examined were :

- Species richness - we adjusted the mean values of richness against number of batteries to a logistic curve : $y=y a\left(1-e^{n}\right)$ in order to estimate the theoretical species richness (Sra) for every river sampled.

- Catch Per Unit of Effort - number of specimen captured/gillnet/hour.

- Sample structure using rank correlation between sample from each battery and total sample.

For each of these parameters the mean and the coefficient of variation defined in $\%$ were plotted against the number of batteries.

\section{RESULTS}

The contribution of each mesh size to total inertia in the PCA analysis shows similar decrease of inertia from mesh size 15 to $25 \mathrm{~mm}$ for the Sinnamary upstream in 1997, Sinnamary downstream and Comté River. From mesh size $35 \mathrm{up}$, inertia presents low values $(<4)$ until net $70 \mathrm{~mm}$ in the three rivers mentioned (Figure 2). In the Sinnamary upstream in 1995, inertia decreases from net $15 \mathrm{~mm}$ to $20 \mathrm{~mm}$ and reaches high value at net $25 \mathrm{~mm}$ showing low values (<2) for meshes larger than $35 \mathrm{~mm}$. In the Malmanoury River inertia increases from gillnets 15 to $30 \mathrm{~mm}$ and reaches low values $(<2)$ from mesh $40 \mathrm{~mm}$ on (Figure 2).

In addition, mesh size 40 to 70 brings few additional species : 3 at Sinnamary downstream station, 2 in the Malmanoury River, 1 in the Comte River and none in the 2 samples from the upstream part of the Sinnamary River.

There were collected 4,121 specimens distributed in 74 species in the five stations sampled. 38 species were sampled at the Comte River and 15 species at the Malmanoury River. At the Sinnamary upstream 95, Sinnamary upstream 96 and Sinnamary downstream the total of species collected were 43,44 and 32 , respectively (Table II). Adjusted curves of sample species richness versus number of batteries show a clear decline in the slope of three rivers sampled (Comté, Sinnamary upstream 96 and Sinnamary downstream). In those rivers the percentage of the theoretical species richness 
(Sra) reached by four batteries is high : $78.8 \%$ of $43.9 ; 82.1 \%$ of 43.7 and $79.3 \%$ of 27.1, respectively (Figure 3). For the two other samples (Malmanoury and Sinnamary upstream 95), the adjusted curves appears like straight lines and the number of species given by four batteries is low : $56.7 \%$ of 15.7 and $59.1 \%$ of 48.7 , respectively (Figure 3). The coefficient of variation displays homogenous values from 3 batteries on. At this level, variance varies from $6.6 \%$ in the Sinnamary upstream 96 to $13.1 \%$ in the Malmanoury River, where the number of species is low.

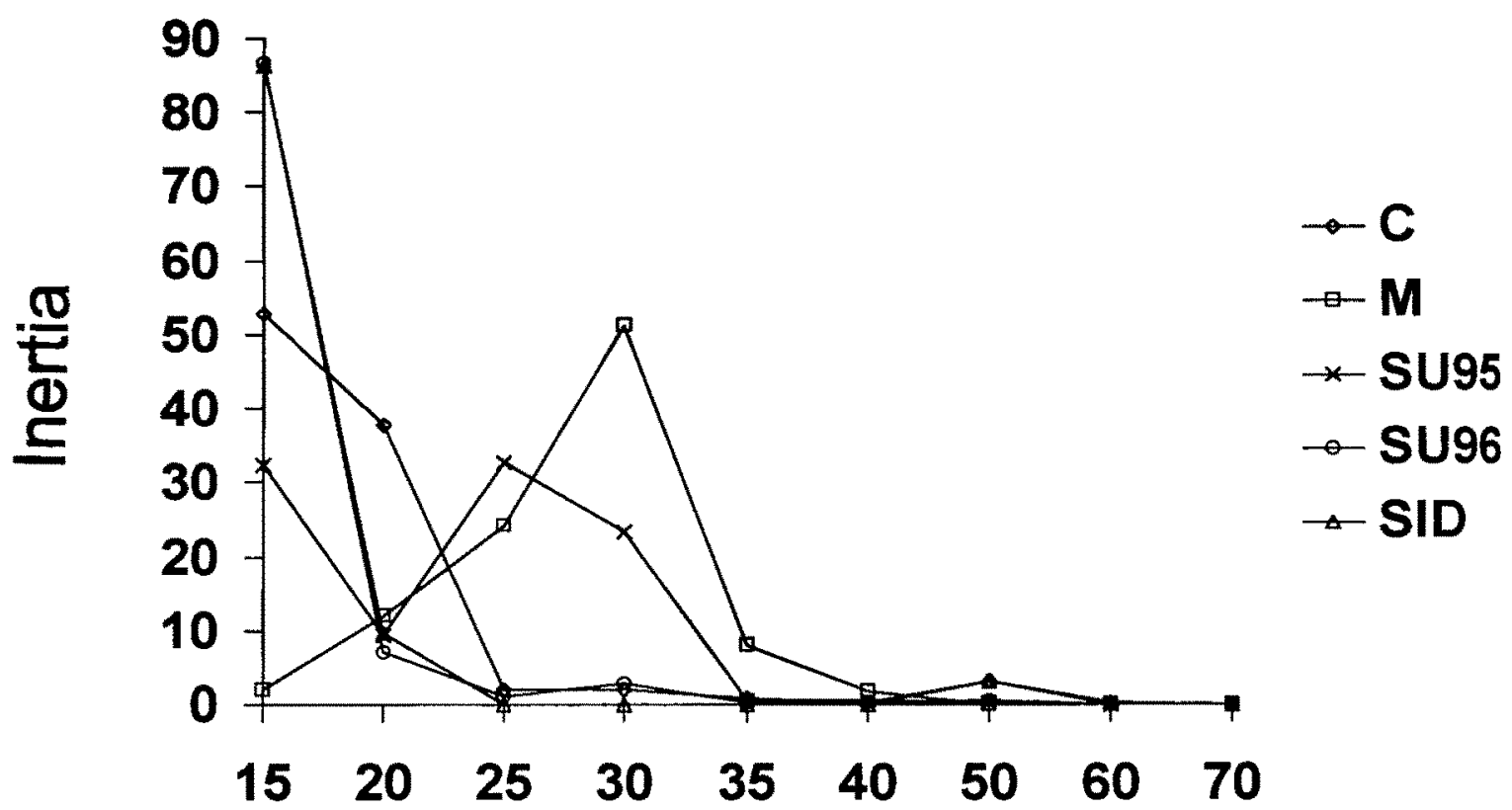

\section{Gillnet mesh size}

\section{Figure 2}

Contributions of each gillnet mesh size to total inertia. $\mathbf{C}=$ Comté River ; M = Malmanoury River ; SU95 = Sinnamary upstream 95 ; SU96 = Sinnamary upstream 96 ; SID = Sinnamary downstream.

\section{Figure 2}

Contribution de chaque maille à l'inertie totale. $\mathbf{C}=$ Comté ; $\mathbf{M}=$ Malmanoury ; SU95 = Sinnamary en amont $1995 ;$ SU96 = Sinnamary en amont 1996 ; SID = Sinnamary en aval.

Plot of the mean rank correlation between the total sample and the samples from increasing batteries of gillnets, chosen randomly, are asymptotic curves but no clear breaking in slope is evidenced. The coefficient of variation declines continuously from 1 to 6 batteries but reaches low values from 3 batteries where the coefficient of variation varies between $2.6 \%$ (Malmanoury River) and $3.7 \%$ (Sinnamary upstream 95). However, stabilized values are observed at two/three batteries (Malmanoury and Sinnamary upstream 96) and at three/four batteries (Sinnamary upstream 95), but downs afterwards (Figure 4). 


\section{Table II}
Frequency of species sampled at the Sinnamary, Comté and Malmanoury River, French Guiana.

\section{Tableau II \\ Fréquence des espèces échantillonnées sur le Sinnamary, la Comté et la Malmanoury, Guyane française.}

\begin{tabular}{lcccc}
\hline ORDER & Comté & Malmanoury & Sinnamary \\
upstream & Sinnamary & Sinnamary \\
Family & & 1995 & 1996 & Total \\
Genus and species & & downstream & \\
\hline
\end{tabular}

\section{BELONIFORMES}

Belonidae

Pseudotylosorus microps

CHARACIFORMES

\section{Anastomidae}

Leporinus friderici

Leporinus despaxi

Leporinus fasciatus

Leporinus gossei

Leporinus granti

Leporinus pellegrini

Characidae

Acestrorhynchus falcatus

Acestrorhynchus microlepis

Characidae

Astyanax bimaculatus

Astyanax polylepis

Bivibranchia bimaculata

Bryconops melanurus

Bryconops caudomaculatus

Bryconops affinis

Charax gibbosus

Hemigrammus unilineatus

Moenkhausia collettii

Moenkhausia comma

Moenkhausia georgiae

Moenkhausia oligolepis

Moenkhausia surinamensis

Piabucus dentatus

Poptella orbicularis

Triportheus rotundatus

Characidiidae

Characidium sp. 1

Curimatidae

Chilodus zunevei

Curimata cyprinoides

Cyphocarax spilurus

Cyphocharax helleri

Cyphocharax sp. 1

Erythrinidae

Hoplias aimara

Hoplias malabaricus

Hemiodidae

Hemiodopsis quadrimaculatus

Hemiodus unimaculatus

Lebiasinidae

Pyrrhulina filamentosa

Serrasalmidae

Myleus rhomboidalis

Myleus ternetzi

Serrasaimus humeralis 
Table II (Continued)

\begin{tabular}{|c|c|c|c|c|c|c|}
\hline $\begin{array}{l}\text { ORDER } \\
\text { Family } \\
\text { Genus and species }\end{array}$ & Comté & Malmanoury & $\begin{array}{c}\text { Sinnamary } \\
\text { upstream } \\
1995\end{array}$ & $\begin{array}{c}\text { Sinnamary } \\
\text { upstream } \\
1996\end{array}$ & $\begin{array}{c}\text { Sinnamary } \\
\text { downstream }\end{array}$ & Total \\
\hline
\end{tabular}

\section{CLUPEIFORMES}

\section{Clupeidae}

Pellona flavipinnis

Engraulidae

Anchovia surinamensis

Anchoviella sp.

Lycengraulis batesii

\section{ELOPIFORMES}

\section{Megalopidae}

Megalops atlanticus

\section{GYMNOTIFORMES}

Hypopomidae

Parupygus savannensis

Sternopygidae

Eigenmannia virescens

Sternopygus macrurus

\section{PERCIFORMES}

Centropomidae

Centropomus parallelus

\section{Cichlidae}

Aequidens guianensis

Crenicichla saxatilis

Geophagus surinamensis

Heros severus

Satanoperca sp. aff. leucosticta

\section{Scianidae}

Plagioscion squamosissimus

Stellifer microps
9

10

- 2

1

44

2

10

3

1

4

9

5

21

3

6

154

2

3

8

SILURIFORMES

Ageneosidae

Ageneiosus brevifilis

Ageneiosus sp.

Auchenipteridae

Auchenipterus nuchalis

Parauchenipterus galeatus

Parauchenipterus nodosus

Tatia intermedia

Callichthyidae

Corydoras spilurus

Doradidae

Doras carinatus

Loricariidae

Ancistrus hoplogenis

Ctenoloricaria maculata

Harttia surinamensis

Hypostomus plecostomus

Lithoxus planquettei

Loricaria cataphracta

Loricaria gr. cataphracta

Pimelodidae

Pimelodella cristata

Pimelodus ornatus

Pseudoplatystoma fasciatum

Rhamdia quelen

-

Number of species

Number of specimens
11

4

40

18

4

4
$-\quad 2$

1

1

59

80

4

94

$\begin{array}{lll}290 & 238 & 662\end{array}$

83

72

2

- 2

103

77

4

5

9

1

$\begin{array}{llll}1 & - & 4\end{array}$

2

22

5

$\begin{array}{lll}2 & - & 7\end{array}$

$\begin{array}{lll}2 & - & \\ - & -\end{array}$

- 4 - 4

$\begin{array}{lll}- & 1 & 10\end{array}$

-

- 8

1

8

4

$\begin{array}{lll}5 & 3 & 8 \\ 2 & 1 & 4\end{array}$

$\begin{array}{lll}2 & 1 & 4 \\ - & - & 1\end{array}$

$\begin{array}{lll}- & - & 1 \\ - & - & 2\end{array}$

$44 \quad 32$

74

200

870

2214

479 

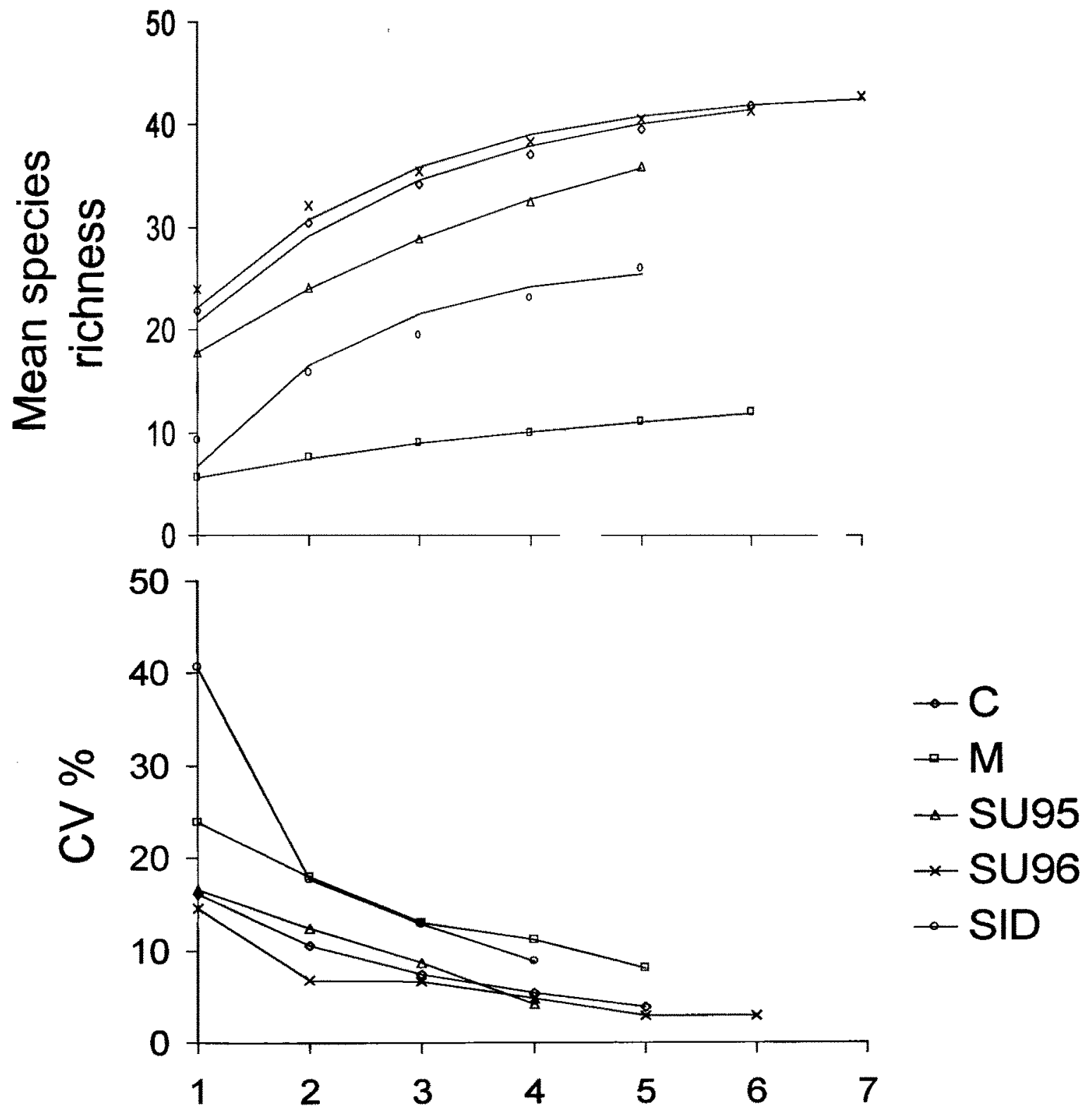

Number of batteries

Figure 3

Coefficient of variation (CV) and adjusted curves of species richness. Marks represent average of species richness. River codes are the same as those of Figure 2.

Figure 3

Coefficient de variation $(\mathrm{CV})$ et courbes de richesse spécifique ajustées. Les symboles représentent la moyenne de la richesse spécifique. Les codes des cours d'eau sont les mêmes que ceux de la Figure 2. 

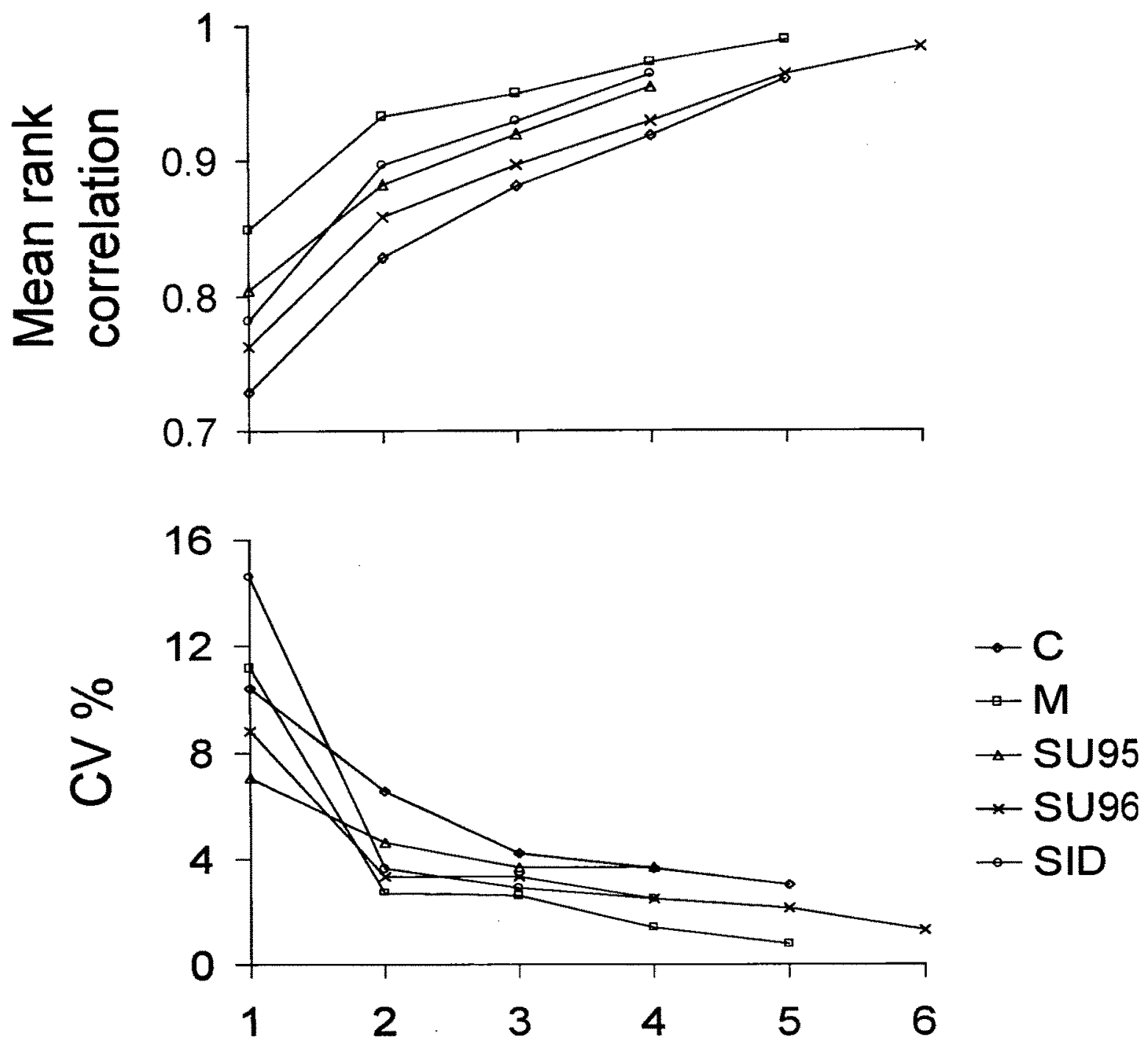

\section{Number of batteries}

Figure 4

Coefficient of variation of Spearman correlation (CV) between total sample structure and those of batteries formed by mixed gillnets mesh size randomly chosen. River codes are the same as those of Figure 2.

\section{Figure 4}

Coefficient de variation de la corrélation de Spearman (CV) entre la structure de l'échantillon total et celle des batteries reconstituées aléatoirement. Les codes des cours d'eau sont les mêmes que ceux de la Figure 2.

The CPUE displays large variation from sample to sample but the mean is surprisingly well estimated by a unique battery. However, the variance of this estimate from one battery is very high. The variance downs, as the numbers of batteries increases and at 3 batteries on values are close. The coefficient of variation at this number of batteries varies between $15.8 \%$ in the Malmanoury and $21.7 \%$ at the Comté River (Figure 5). 

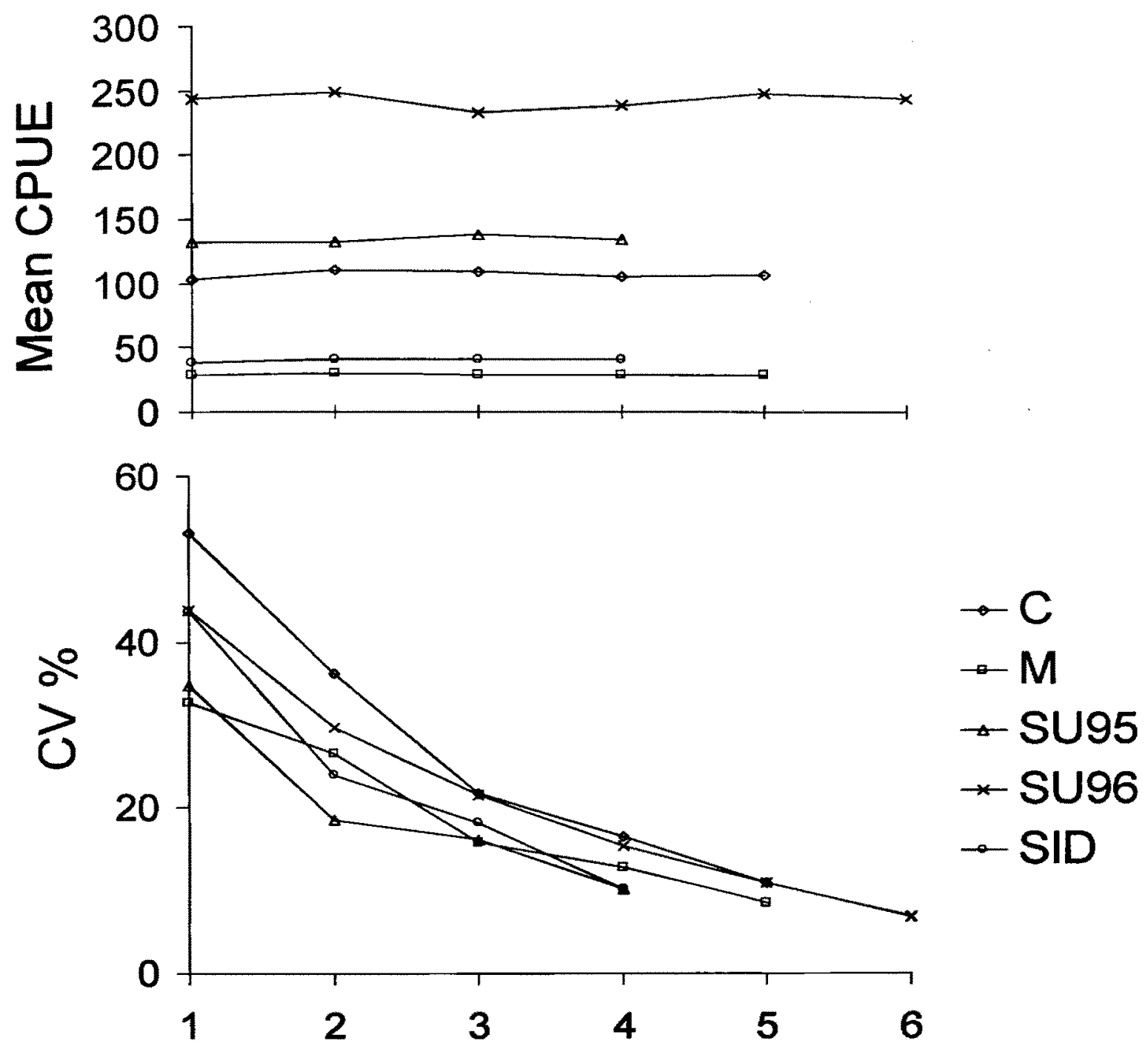

\section{Number of batteries}

Figure 5

Coefficient of variation of CPUE (CV) values by battery of gillnet of the five sampling sites. River codes are the same as those of Figure 2.

Figure 5

Coefficient de variation du CPUE (CV) par batterie de filets maillants. Les codes des cours d'eau sont les mêmes que ceux de la Figure 2.

\section{DISCUSSION}

In this study the contribution of each gillnet mesh size to total variance (inertia) decreases until still regularly, but the decrease is not similar for all rivers. Despite differences in number of batteries used in each river (Sinnamary upstream 96, 7 batteries ; Sinnamary upstream 95 and Sinnamary downstream, 5 ; Comté and Malmanoury River, 6) gillnets mesh sizes $15,20,25,30$ and $35 \mathrm{~mm}$ showed significant contribution to total inertia, whereas gillnets of mesh sizes $40,50,60$ and $70 \mathrm{~mm}$ had low contribution. This 
suggests that nets of mesh sizes 15 to $35 \mathrm{~mm}$ are more adequate to sample fish communities in the rivers studied than nets of mesh sizes 40 to $70 \mathrm{~mm}$. However, the inertia variation observed among nets in the rivers sampled can also be explained partly by the characteristics of the habitat (e.g. running velocity, kind of substrate, type of riverbank) rather than net catch (BOUJARD et al., 1990). Although, other factors seems to be important. Indeed, tropical fish faunas, like those found in French Guiana, are naturally formed by a high proportion of small species (<10 cm) (WELCOMME, 1979). This may explain the expressive contribution of net mesh size $15 \mathrm{~mm}$ in most of stations. However, the differences observed among gillnets 15 to $35 \mathrm{~mm}$ are also related to the abundance of some species. That is the case of Acestrorhynchus microlepis, Bryconops caudomaculatus and Cyphocharax spilurus in the Sinnamary upstream 96 (mesh size $15 \mathrm{~mm}$ ) ; Bryconops caudomaculatus and Hemiodopsis quadrimaculatus in the Sinnamary upstream 95 (mesh size $15 \mathrm{~mm}$ ). Parauchenipterus galeatus is the main responsible for the peak observed at gillnet $30 \mathrm{~mm}$ in the Malmanoury River.

By the way, the low capture of large mesh size gillnets (40 to $70 \mathrm{~mm}$ ) would be due to fish behaviour, especially that of large predators like Hoplias aimara and Ageneiosus brevifilis. These fishes are almost always tangled in gillnets of small mesh, where they are attracted by movements of caught fish.

Because we are interested in fish communities we did not consider here the biomass. Accidental capture of very large specimens introduce a great variability mainly generated by chance and so bringing an information of difficult ecological interpretation.

In spite of the problems related to the capture of fish by gillnets, our results are in accord with the suggestion of HELSER and CONDREY (1991) of mixing different mesh size in order to reduce bias due to selectivity of gillnets. In our study the combinations of gillnets mesh 15 to $35 \mathrm{~mm}$ seems to be satisfactory for sampling the fish communities of the large rivers sampled.

In this paper the number of repeated set of nets was estimated based on two type of statistics (mean and variance of estimations randomly chosen in a system of increasing number of batteries of gillnets) from three parameters : CPUE, species richness and sample structure (rank correlation).

The estimation of the fish density (CPUE) does not vary much with increasing number of batteries in all the rivers sampled, but chance seems to be an important factor that accounts for the high variance observed among the samples. However, this variance may be also due to other factors such as seasonal variability (e.g., Sinnamary upstream 1995 and 1996) or river size (e.g., the Malmanoury, a coastal river compared to the other rivers sampled). CPUE results display that at 3 batteries of gillnets relative low values is reached by variance, which afterwards displays little variation. This allow us to assume that from 3 batteries of gillnets on we get a good estimator of the density of the fish communities sampled.

Species richness and sample structure do not stabilize even beyond 5 batteries, but their evolution in function of the number of batteries is almost always asymptotic. The coefficient of variation of the mean rank correlation displays plateaus from 2 to 3 or from 3 to 4 batteries in different samples and in all of them after 3 batteries variance do not vary very much. This suggests that from 3 batteries on we have a good estimation of the sampling structure. Species richness variance decreases fast from 1 to 5 batteries. However, from 3 batteries on, variance values vary slightly in all sampling. The adjusted points in relation to theoretical species richness appointed to an average of $71.2 \%$ species sampled at 3 batteries of gillnets. This represents an expressive number of the species of the fish community sampled, even if we consider that species richness is a factor that 
changes accordingly to the size of the sample (MAGURRAN, 1988) and it may be not well evaluated for the effort of sampling employed in this study.

Despite the parameters used present confidence limits rather than punctual results, these seems sensitive enough to determinate the best number of batteries. Thus, 3 batteries seem to be a good compromise between sampling effort and accuracy of results that give us a reliable image from the fraction of the fish community sampled. This number of batteries takes account of the material possibilities of a research team and the habitat density in a determined section of the river where the use of gillnets is feasible. However, because the data set used for this study does not cover the whole range of conditions in French Guiana rivers, one could use an additional battery providing a sufficient fishing crew.

If the use of mixed mesh size of gillnets and repeated batteries are useful to sampling fish communities of large rivers, the practices of standardize this kind of gear is not usual. Thus, since different rivers present different specific composition of the fish fauna, it seems important to include the standardization of gillnets in sampling protocols.

\section{ACKNOWLEDGEMENTS}

Special thanks to the team of the Laboratoire d'Hydrobiologie of the Institut de Recherche pour le Développement (IRD) - Cayenne for their support on field and laboratory. We are grateful to Pier Angelo Tognini Filho, bachelor student at the Department of Computation Sciences - Universidade Católica de Goiás, Brazil, for the statistical software developed to random chose of numbers used in this paper. We thank two anonymous reviewers for their comments and suggestions. F.L.T.G. received a grant from IRD.

\section{REFERENCES}

BACKIEL T., WELCOMME R.L., 1980. Guidelines for sampling fish in inland waters. FAO Technical Paper No. 33, 167 p.

BAYLEY P.B., 1982. Central Amazon fish populations : Biomass, production and some dynamic characteristics. PhD Thesis, Dalhousie University, $330 \mathrm{p}$.

BAYLEY P.B., 1985. Sampling problems in freshwater fisheries. Proc. 4th. Brit. Freshw. Fish. Conf., 3-11.

BOUJARD T., PASCAL M., MEUNIER F.J., 1990. Micro-répartition spatio-temporelle du peuplement ichtyologique d'un haut bassin fluvial de Guyane, l'Arataye. Rev. Ecol. (Terre Vie), 45, 357-373.

BOUJARD T., PASCAL M., MEUNIER J.F., LE BAIL P.Y., 1997. Poissons de Guyane guide écologique de l'Approuague et de la réserve des Nouragues. Institut National de la Recherche Agronomique. Paris, $219 \mathrm{p}$.

CHURCH M., 1992. Channel morphology and typology. In : P. CALOW and G.E. PETTS (Eds.), The rivers handbook : hydrological and ecological principles. Volume 1. Blackwell Science, Oxford, UK, 526 p.

HAMLEY J.M., 1975. Reviews of gillnet selectivity. J. Fish. Res. Board Can., 32, 1943-1969.

HAMLEY J.M., REGIER H.A., 1973. Direct estimates of gillnet selectivity to Walleye (Stizostedion vitreum vitreum). J. Fish. Res. Can., 30, 817-830. 
HELSER T.E., CONDREY R.E., 1991. A new method of estimating gillnet selectivity, with an example for Spotted Seatrout, Cynocion nebulosus. Can. J. Fish. Aquat. Sci., 48, 487-492.

HENDERSON B.A., WONG J.L., 1991. A method for estimating gillnet selectivity of Walleye (Stizostedion vitreum vitreum) in multimesh multifilament gillnets in Lake Erie, and its application. Can. J. Fish. Aquat. Sci., 48, 2420-2428.

HYNES H.B.N., 1989. Keynote address. In : D.P. DODGE (ed.), Proceedings of the International Large River Symposium (LARS). Can. Spec. Pub. Fish. Aquat. Sci., $106,629$.

JENSEN J.W., 1986. Gillnet selectivity and the efficiency of alternative combinations of mesh sizes for some freshwater fish. Journal of Fish Biology, 28, 637-646.

KELLERHALS R., CHURCH M., 1989. The morphology of Large Rivers : Characterization and management. In : D.P. DODGE (ed.), Proceedings of the International Large River Symposium (LARS). Can. Spec. Pub. Fish. Aquat. Sci., 106, 31-48.

LAGLER K.F., KAPETSKY J.M., STEWART D.J., 1971. The fisheries of the Kafue River Flats, Zambia, in relation to the Kafue Gorge dam. FAO FI : SF/ZAM 11, Tech. Rep. 1, $161 \mathrm{p}$.

LAMARQUE P. 1990. Electrophysiology of fish in electric fields. In : I.G. COWX and P. LAMARQUE (Eds.), Fishing with electricity : applications in freshwater fisheries management. Blackwell Scientific Publications, Oxford, 65-92 p.

MAGURRAN A.E., 1988. Ecological diversity and its measurement. CHAPMAN and HALL, London, UK, $179 \mathrm{p}$.

NELVA A., PERSAT H., CHESSEL D., 1979. Une nouvelle méthode d'étude des peuplements ichtyologiques dans les grands cours d'eau par échantillonnages ponctuels d'abondance. Comptes Rendus de l'Académie des Sciences, Paris, 289(D), 1295-1298.

PERSAT H., COPP G.H., 1990. Electric fishing and point abundance sampling for the ichthyology of large rivers. In : I.G. COWX (ed.), Developments in electric fishing. Fishing New Books, No27 Blackwell Scientific Publications, Oxford, UK.

PLANQUETTE P., KEITH P., LE BAIL P.Y., 1996. Atlas des poissons d'eau douce de Guyane (Tome 1). IEBG, MNHN, INRA, CSP, Ministère de l'Environnement, Paris, $429 \mathrm{p}$.

PONTON D., COPP G.H., 1997. Early dry - season community structure and habitat use of young fish in tributaries of the River Sinnamary (French Guiana, South America) before and after hydrodam operation. Environmental Biology of Fishes, 50, 235-256.

ROJAS-BELTRAN R., 1984. Clé simplifiée des espèces de Siluriformes. Bulletin de Liaison, Groupe de Recherche de Guyane, $63 \mathrm{p}$.

SANTOS G.M. dos, JEGU M., MÉRONA B. de., 1984. Catálogo de peixes comerciais do baixo rio Tocantins; projeto Tucuruí. ELETRONORTE/CNPq/INPA, Manaus, $83 \mathrm{p}$.

SIMIER M., 1998. Initiation au logiciel ADE-4. ORSTOM, Centre ORSTOM de Montpellier. Montpellier, $83 \mathrm{p}$.

TEJERINA-GARRO F.L., FORTIN R., RODRÍGUEZ M.A., 1998. Fish community structure in relation to environmental variation in floodplain lakes of the Araguala River, Amazon Basin. Environmental Biology of Fishes, 51, 399-410.

THIOULOUSE J., CHESSEL D., DOLEDEC S., OLIVIER J.M., 1997. ADE-4 : a multivariate analysis and graphical display software. Statistics and Computing, 7 , 75-83.

WELCOMME R.L., 1979. Fisheries ecology of floodplain rivers. Longman, New York, $317 p$. 